\title{
REFERENCE INTERVALS FOR HAEMATOLOGICAL PARAMETERS IN THE LUSITANO HORSE BREED
}

\author{
Ana Cristina Silvestre-FerreirA ${ }^{1,2}$, Mário Cotovio ${ }^{1,2^{*}}$, Mário MaiA ${ }^{1}$, \\ Felisbina QUEIROGA ${ }^{1,3}, \mathrm{M}^{\mathrm{a}}$ João PIRES ${ }^{1,3}$ and Aura COLAÇO ${ }^{1,2}$ \\ ${ }^{1}$ Department of Veterinary Sciences, ${ }^{2} \mathrm{CECAV}$, Centre for the Animal and Veterinary \\ Sciences, ${ }^{3} \mathrm{CITAB}$, Centre for Research and Technology of Agro-Environment and \\ Biological Sciences, University of Trás-os-Montes and Alto Douro, 5000-801 Vila Real, \\ Portugal
}

(Received 18 January 2018; accepted 25 July 2018)

The Lusitano horse is an autochthonous Portuguese breed with a growing worldwide expansion. Our objective was to establish reference intervals for haematological parameters using the haematological cell counter LaserCyte (IDEXX). For this purpose, blood samples from 100 healthy adult horses ( 13 females and 87 males, ranging from 3 to 25 years of age) were analysed. The reference intervals were estimated following the ASVCP guidelines with the Reference Value Advisor software. The obtained reference intervals were $6.4-10.1 \times 10^{12} / \mathrm{L}$ for red blood cells, 30.6-45.1\% for haematocrit, 11.6-17.1 g/dL for haemoglobin, 42.8$53.2 \mathrm{fL}$ for mean corpuscular volume (MCV), 15.5-20.8 pg for mean corpuscular haemoglobin (MCH), 33.7-39.4 g/dL for mean corpuscular haemoglobin concentration, $17.8-20.3 \%$ for red cell distribution width (RDW), $4.5-10.1 \times 10^{9} / \mathrm{L}$ for white blood cells, $2.2-6.0 \times 10^{9} / \mathrm{L}$ for neutrophils, $0.9-4.9 \times 10^{9} / \mathrm{L}$ for lymphocytes, $0.2-0.5 \times 10^{9} / \mathrm{L}$ for monocytes, $0.1-0.6 \times 10^{9} / \mathrm{L}$ for eosinophils, $0.0-0.1 \times$ $10^{9} / \mathrm{L}$ for basophils, $78.5-172.2 \mathrm{~K} / \mathrm{mL}$ for platelets, $4.3-9.4 \mathrm{fL}$ for mean platelet volume, $18.8-24.2 \%$ for platelet distribution width, and $0.06-0.12 \%$ for plateletcrit. LaserCyte equine reference intervals are transferable to the Lusitano horse for 18 of the 22 analytes studied. Regarding age, significant statistical differences were observed for MCV, RDW, neutrophils and lymphocytes between the mean values of young ( $3-6$ years old), middle-aged ( $7-14$ years old) and old (> 15 years old) age groups. $\mathrm{MCH}$ means were statistically significantly different between the three age groups. The haematological reference intervals established in this study might represent a valuable and applicable tool for haematological assessment of adult Lusitano horses, providing useful information that helps clinicians to interpret clinical data. breed

Key words: Haematological reference intervals, Lusitano horse, equine

*Corresponding author; E-mail: mcotovio@utad.pt; Phone: 00351 259350655, Fax: 00351350480 
The Lusitano horse is an autochthonous Portuguese breed considered to be the most important native equine breed in Portugal with a growing worldwide expansion (Vicente et al., 2009). This breed has also contributed to the development of horse breeds in other parts of the world, especially on the American continent (Luis et al., 2007). The Lusitano horse is considered a 'hot' breed and a direct descendant of the Iberian horse, being one of the oldest saddle breeds in the world. It is an excellent horse for bullfighting and for almost all modern equestrian sports. The Lusitano breed is considered a minority breed with only 20,000 specimens all around the world (APSL, 2012), with a registered census of about 5000 breeding mares, about half of which are kept in Portugal and the remainder are spread throughout the world (Vicente et al., 2009). At present, 32 different countries breed and register Lusitano horses. Besides Portugal, there are important Nucleus and Breeders' Associations in countries including Australia, Belgium, Brazil, Colombia, Denmark, Ecuador, Finland, France, Germany, Italy, Mexico, The Netherlands, Norway, South Africa, Spain, Sweden, Switzerland, United Kingdom, and the United States of America (APSL, 2012).

The Lusitano horse has a very long history, with pedigree information dating back to the beginning of the 19th century, and presents nowadays a mean inbreeding of 11.34\% (Vicente et al., 2012), which is similar to that observed in Pura Raza Española (Valera et al., 2005), Lipizzaner (Zechner et al., 2002) and Thoroughbred horses (Cunningham et al., 2001). Considering that the Lusitano horse is an ancestral breed kept with some levels of inbreeding, it is of relevance for the study of haematological parameters and the respective confidence intervals.

The haematological reference intervals commonly used in veterinary medicine can be influenced by internal factors like age, sex or breed, as well as factors such as environment, lifestyle and time of the year (Piccione et al., 2008; Fazio et al., 2011; Friedrichs et al., 2012; Vazzana et al., 2014). Thus, published reference values may not be directly applicable to this particular breed. To the best of the author's knowledge, there are no studies about haematological reference intervals (RI) in Lusitano horses. In view of this, our aim was to establish haematological RI for Lusitano horses using the LaserCyte (IDEXX) in a well-defined reference sample population, with well-characterised analytical methods, and to compare them to the RI established by the manufacturer for horses in general.

\section{Materials and methods}

\section{Study population}

This study was conducted in northern Portugal using purebred Lusitano horses from private owners stabled in their normal environment. The study included 100 adult Lusitano horses (13 females and 87 males). To study the effect of age on the haematological profile, the horses were divided into three groups: 
young (3-6 years old; $\mathrm{n}=41)$, middle-aged $(7-14$ years old; $\mathrm{n}=36$ ) and old $(>15$ years old; $n=23)$. Regarding the effect of sex, the horses were grouped into males (non-castrated) and females.

The horses were kept under natural photoperiod and ambient temperature (climate classification: warm temperate with dry summers) in individual stalls, with free access to water and were fed twice a day with hay ( $2 \%$ body weight) and commercial feed (14\% protein and $4.35 \%$ fat). In general, all animals were exercised three times a week for approximately one hour on a regular basis. All owners gave their informed consent to the use of their animals' data. The study was ethically approved by the board of the University of Trás-os-Montes e Alto Douro Veterinary Teaching Hospital as complying with the Portuguese legislation for the protection of animals (Law no. 92/1995, 12 September), and followed the ASVCP guidelines (Friedrichs et al., 2012). For the present study, inclusion and exclusion criteria were established prior to sample collection, as follows: only adult healthy animals, routinely dewormed and vaccinated against tetanus and influenza in the previous 6 months, were included. For each horse the owners or caretakers stated the normal physical condition and regular activity, lack of signs of disease or any health problems in the previous 6 months. Before blood sampling, all animals had a normal complete physical examination including visual inspection, rectal temperature, heart and respiratory rates, appearance of mucous membranes and capillary refill time, pulmonary, cardiac and abdominal auscultation. Animals that were deemed unhealthy, had undergone surgery or received any medication in the previous 6 months, as well as pregnant and lactating mares were excluded. Samples from animals that were excited or agitated at the time of sampling were also excluded.

\section{Sample collection and haematological analyses}

Blood samples were collected during the spring, in the morning period from non-fasted animals, and obtained by jugular venepuncture with a $5-\mathrm{mL}$ syringe and a 20-gauge needle, and placed into a 1-mL EDTA K3 container (IDEXX Vetcollect). All samples were kept at $2-4{ }^{\circ} \mathrm{C}$ during transportation, analysed within $4 \mathrm{~h}$ of collection and processed at the Clinical Pathology Laboratory of the University of Trás-os-Montes e Alto Douro Veterinary Teaching Hospital. The samples were analysed by the use of LaserCyte (IDEXX), previously validated for use in equine medicine (Silva et al., 2010; Silvestre-Ferreira et al., 2010a, 2010b) and following the manufacturer's instructions. Samples with agglutination signs were rejected. The studied parameters were red blood cells (RBC), haematocrit (HTC), haemoglobin (HGB), mean corpuscular volume (MCV), mean corpuscular haemoglobin $(\mathrm{MCH})$, mean corpuscular haemoglobin concentration (MCHC), red cell distribution width (RDW), white blood cells (WBC), neutrophils (NEU), lymphocytes (LYM), monocytes (MONO), eosinophils (EOS), basophils (BASO), 
platelets (PLT), mean platelet volume (MPV), platelet distribution width (PDW) and plateletcrit (PCT).

\section{Statistical analyses}

The calculations of basic descriptive statistics, RI, their confidence interval limits (90\%) and the linear regression coefficients of age on the analytes were performed with the Reference Value Advisor V 2.1 software, a free set of macroinstructions to calculate RI with Microsoft Excel (Geffré et al., 2011). The RI were estimated according to the ASVCP guidelines (Friedrichs et al., 2012), namely those recommended for sample sizes ( $\mathrm{x}$ ) included in the interval of $40 \leq \mathrm{x}<120$. The Anderson-Darling test was used to assess normality, and the outliers were identified by Tukey and Dixon-Reed methods and eliminated after visual evaluation. Depending on the distribution, the parametric or robust method with or without Box-Cox transformation was applied to calculate 95\% population-based RI. Following the guidelines (Horowiz et al., 2008; Friedrichs et al., 2012; Sample et al., 2015) in order to determine whether LaserCyte (IDEXX) equine RI are transferable to Lusitano horses, the acceptance criterion was as follows: after the elimination of outliers, less than $10 \%$ of the results fell outside the LaserCyte (IDEXX) equine RI. This method replicates the binomial test.

The calculations to investigate the eventual significant differences in relation to sex and age groups (young, middle-aged, old) were performed with IBM SPSS V.21.0. The normality assumption was checked with the Shapiro-Wilk test and homoscedasticity with Levene's test. The data proving to be not normally distributed were subjected to Independent-Samples Mann-Witney U Test to investigate if the distribution was the same across sex categories. The normally distributed analytes were subjected to a one-way analysis of variance (ANOVA) and Robust Tests of Equality of Means (Welch, Brown-Forsythe). Multiple comparisons among means were made by the Games-Howell method. Statistical significance was set at $\mathrm{P}<0.05$.

\section{Results}

One hundred adult Lusitano horses (13 females with a mean age of $10 \pm$ 6.1 years ranging from 3 to 19 years, and 87 males with a mean age of $9.2 \pm 5.5$ years ranging from 3 to 25 years) were enrolled in the study.

The established reference intervals are presented in Table 1. LaserCyte (IDEXX) equine RI are not transferable to Lusitano horses in parameters MCHC (33.7-39.6 g/dL), WBC (4.1-9.4 10\%/L), LYM (1-4.7 10\%/L) and BASO (0-0.1 $10^{9} / \mathrm{L}$ ) because, after excluding the outliers, more than $10 \%$ of the samples fell outside the LaserCyte (IDEXX) RI values. 


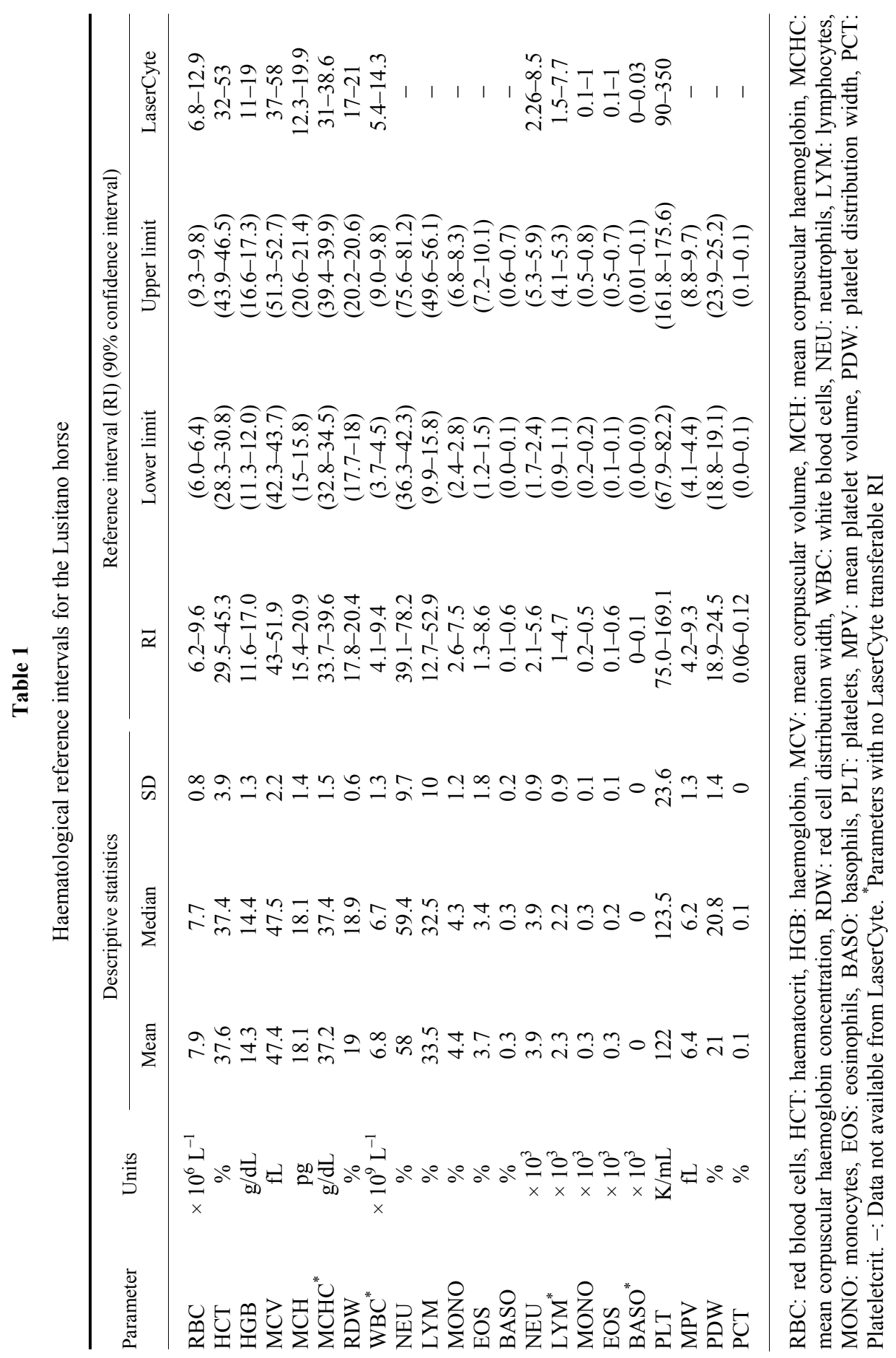


Table 2

Effect of age on haematological parameters in the Lusitano horse

\begin{tabular}{|c|c|c|c|c|}
\hline \multicolumn{5}{|c|}{ Age effect } \\
\hline Parameter & $\begin{array}{c}\text { Young } \\
(\mathrm{n}=41)\end{array}$ & $\begin{array}{c}\text { Middle-aged } \\
\quad(\mathrm{n}=36)\end{array}$ & $\begin{array}{c}\text { Old } \\
(\mathrm{n}=23)\end{array}$ & \multirow[t]{2}{*}{ Significance $(\mathrm{P})$} \\
\hline & & Mean (SD) & & \\
\hline $\mathrm{a}$ & $\begin{array}{c}8.1212^{\mathrm{a}} \\
(0.97668)\end{array}$ & $\begin{array}{c}7.9375^{\mathrm{a}} \\
(0.94773)\end{array}$ & $\begin{array}{c}7.6200^{\mathrm{a}} \\
(0.76968)\end{array}$ & $\begin{array}{l}\text { Young vs. Middle-aged, } \mathrm{P}=0.682 \\
\text { Young vs. Old. } \mathrm{P}=0.073 \\
\text { Middle-aged vs. Old, } \mathrm{P}=0.350\end{array}$ \\
\hline $\begin{array}{l}\text { MCV } \\
\text { (fL) }\end{array}$ & $\begin{array}{l}46.017^{\mathrm{a}} \\
(1.6432)\end{array}$ & $\begin{array}{l}48.111^{\mathrm{b}} \\
(1.4983)\end{array}$ & $\begin{array}{l}49.227^{\mathrm{b}} \\
(2.1922)\end{array}$ & $\begin{array}{l}\text { Young vs. Middle-aged, } \mathrm{P}<0.001 \\
\text { Young vs. Old, } \mathrm{P}<0.001 \\
\text { Middle-aged vs. Old, } \mathrm{P}=0.104\end{array}$ \\
\hline $\begin{array}{l}\mathrm{MCH} \\
(\mathrm{pg})\end{array}$ & $\begin{array}{l}17.4468^{\mathrm{a}} \\
(1.2647)\end{array}$ & $\begin{array}{l}18.3106^{\mathrm{b}} \\
(1.07395)\end{array}$ & $\begin{array}{l}19.2191^{\mathrm{c}} \\
(1.18455)\end{array}$ & $\begin{array}{l}\text { Young vs. Middle-aged, } \mathrm{P}=0.005 \\
\text { Young vs. Old, } \mathrm{P}<0.001 \\
\text { Middle-aged vs. Old, } \mathrm{P}=0.015\end{array}$ \\
\hline $\begin{array}{l}\text { RDW } \\
(\%)\end{array}$ & $\begin{array}{l}19.215^{\mathrm{a}} \\
(0.5829)\end{array}$ & $\begin{array}{l}18.725^{\mathrm{b}} \\
(0.5101)\end{array}$ & $\begin{array}{l}18.695^{\mathrm{b}} \\
(0.5296)\end{array}$ & $\begin{array}{l}\text { Young vs. Middle-aged, } \mathrm{P}=0.001 \\
\text { Young vs. Old, } \mathrm{P}=0.002 \\
\text { Middle-aged vs. Old, } \mathrm{P}=0.976\end{array}$ \\
\hline $\begin{array}{l}\text { NEU } \\
(\%)\end{array}$ & $\begin{array}{l}51.668^{\mathrm{a}} \\
(8.4615)\end{array}$ & $\begin{array}{l}61.833^{\mathrm{b}} \\
(8.0355)\end{array}$ & $\begin{array}{l}64.736^{\mathrm{b}} \\
(4.7794)\end{array}$ & $\begin{array}{l}\text { Young vs. Middle-aged, } \mathrm{P}<0.001 \\
\text { Young vs. Old, } \mathrm{P}<0.001 \\
\text { Middle-aged vs. Old, } \mathrm{P}=0.205\end{array}$ \\
\hline $\begin{array}{l}\text { LYM } \\
(\%)\end{array}$ & $\begin{array}{l}39.924^{\mathrm{a}} \\
(9.4417)\end{array}$ & $\begin{array}{l}29.311^{\mathrm{b}} \\
(7.9741)\end{array}$ & $\begin{array}{l}27.391^{\mathrm{b}} \\
(4.9254)\end{array}$ & $\begin{array}{l}\text { Young vs. Middle-aged, } \mathrm{P}<0.001 \\
\text { Young vs. Old, } \mathrm{P}<0.001 \\
\text { Middle-aged vs. Old, } \mathrm{P}=0.498\end{array}$ \\
\hline $\begin{array}{l}\text { NEU } \\
\left(\times 10^{3}\right)\end{array}$ & $\begin{array}{c}3.5715^{\mathrm{a}} \\
(0.69424)\end{array}$ & $\begin{array}{c}4.1044^{b} \\
(0.99192)\end{array}$ & $\begin{array}{c}4.2532^{\mathrm{b}} \\
(0.84631)\end{array}$ & $\begin{array}{l}\text { Young vs. Middle-aged, } \mathrm{P}=0.024 \\
\text { Young vs. Old, } \mathrm{P}=0.007 \\
\text { Middle-aged vs. Old, } \mathrm{P}=0.817\end{array}$ \\
\hline $\begin{array}{l}\text { LYM } \\
\left(\times 10^{3}\right)\end{array}$ & $\begin{array}{c}2.8607^{\mathrm{a}} \\
(1.07559)\end{array}$ & $\begin{array}{c}1.9375^{\mathrm{b}} \\
(0.61019)\end{array}$ & $\begin{array}{c}1.7968^{\mathrm{b}} \\
(0.45353)\end{array}$ & $\begin{array}{l}\text { Young vs. Middle-aged, } \mathrm{P}<0.001 \\
\text { Young vs. Old, } \mathrm{P}<0.001 \\
\text { Middle-aged vs. Old, } \mathrm{P}=0.579\end{array}$ \\
\hline $\begin{array}{l}\text { PDW } \\
(\%)\end{array}$ & $\begin{array}{l}20.668^{\mathrm{a}} \\
(1.0558)\end{array}$ & $\begin{array}{l}21.175^{\mathrm{a}} \\
(1.4389)\end{array}$ & $\begin{array}{l}21.277^{\mathrm{a}} \\
(1.6245)\end{array}$ & $\begin{array}{l}\text { Young vs. Middle-aged, } \mathrm{P}=0.198 \\
\text { Young vs. Old, } \mathrm{P}=0.266 \\
\text { Middle-aged vs. Old, } \mathrm{P}=0.968\end{array}$ \\
\hline
\end{tabular}

Multiple comparisons among means were made by the Games-Howell method. RBC: red blood cells, MCV: mean corpuscular volume, MCH: mean corpuscular haemoglobin, RDW: red cell distribution width, NEU: neutrophils, LYM: lymphocytes, PDW: platelet distribution width

Regarding the effect of age on the analytes, data of all the animals were analysed by a simple linear regression method and a negative regression coefficient (b) was found for RBC ( $\mathrm{b}=-0.040, \mathrm{P}<0.017)$, RDW \% $(\mathrm{b}=-0.038, \mathrm{P}<$ $0.001)$, LYM \% $(\mathrm{b}=-0.936, \mathrm{P}<0.0001)$ and LYM $(\mathrm{b}=-0,081, \mathrm{P}<0.0001)$; 
while a positive regression coefficient (b) was observed for MCV $(\mathrm{b}=0.222, \mathrm{P}<$ $0.0001)$, MCH $(\mathrm{b}=0.121, \mathrm{P}<0.0001)$, NEU \% $(\mathrm{b}=0.963, \mathrm{P}<0.0001)$, NEU $(\mathrm{b}=0.047, \mathrm{P}<0.003)$ and PDW \% $(\mathrm{b}=0.061, \mathrm{P}<0.014)$. No statistically significant results were found for the other parameters analysed.

In order to better clarify the effect of age, the mean and standard deviation for the parameters that revealed significantly different regression coefficients were calculated within each age group, and the Games-Howell method was used to make multiple comparisons among age group means for each of those analytes (Table 2). For all these parameters the mean of the young group differed from the means of the other two groups. Only the parameter MCH presented statistically significant differences between the three age groups. For RBC and PDW no significant differences were observed among the age groups, despite the previously obtained significant difference of the regression coefficients.

A significant effect of sex on RBC, HCT, HGB, WBC, MONO \%, BASO $\%$ and LYM was demonstrated (Table 3 ). All of the above parameters were significantly higher in females than in males except for MONO \% and BASO \% which were significantly higher in males than in females $(\mathrm{P}<0.05)$.

Table 3

Effect of sex on haematological parameters in the Lusitano horse

\begin{tabular}{|c|c|c|c|c|c|}
\hline \multirow{3}{*}{$\begin{array}{l}\text { Haematological } \\
\text { parameter }\end{array}$} & \multicolumn{5}{|c|}{ Sex effect } \\
\hline & \multicolumn{2}{|c|}{ Females $(n=13)$} & \multicolumn{2}{|c|}{ Males $(\mathrm{n}=87)$} & \multirow{2}{*}{$\begin{array}{c}\text { Significance } \\
\text { (P) }\end{array}$} \\
\hline & Mean & $\begin{array}{l}\text { Standard } \\
\text { deviation }\end{array}$ & Mean & $\begin{array}{l}\text { Standard } \\
\text { deviation }\end{array}$ & \\
\hline $\mathrm{RBC}\left(\times 10^{6} \mathrm{~L}^{-1}\right)$ & 8.53 & 0.93 & 7.83 & 0.89 & 0.014 \\
\hline HCT (\%) & 40.56 & 3.38 & 37.12 & 3.84 & 0.004 \\
\hline HGB (g/dL) & 15.40 & 1.07 & 14.16 & 1.32 & 0.003 \\
\hline $\mathrm{WBC}\left(\times 10^{9} \mathrm{~L}^{-1}\right)$ & 7.72 & 1.73 & 6.63 & 1.18 & 0.006 \\
\hline $\operatorname{LYM}\left(\times 10^{3}\right)$ & 2.93 & 1.35 & 2.22 & 0.85 & 0.013 \\
\hline MONO (\%) & 3.55 & 0.84 & 4.55 & 1.24 & 0.008 \\
\hline BASO (\%) & 0.23 & 0.13 & 0.34 & 0.15 & 0.013 \\
\hline
\end{tabular}

The statistical method was a one-way analysis of variance (ANOVA). RBC: red blood cells, HCT: haematocrit, HGB: haemoglobin, WBC: white blood cells, LYM: lymphocytes, MONO: monocytes, BASO: basophils

\section{Discussion}

It is well known that several factors including breed, age (Kramer, 2000; Southwood, 2013), sex, reproductive and athletic status (Piccione et al., 2008; Piccione et al., 2010; Fazio et al., 2011; Bazzano et al., 2014; Vazzana et al., 2014), as well as geographic location and environment (Friedrichs et al., 2012) influence the haematological profiles of horses. Comparative studies on haematological RI are 
difficult to perform due to the use of different samples, methodologies, haematological analysers and interval calculation methods. Additionally, some studies do not specify exactly the reference sample population, making it difficult to determine if RI are appropriate for clinical use (Pritchard et al., 2009; Friedrichs et al., 2012). Finally, most of the time, the absence of appropriate in-house RI leads clinicians to use published RI, or RI from instrument manufacturers, in order to interpret laboratory results (Friedrichs et al., 2012; Leidinger et al., 2015).

In the present study, the RI for haematological parameters were determined in Lusitano horses using the haematological cell counter LaserCyte (IDEXX). The resulting haematological RI of some parameters (Table 1) partially overlap between Lusitano horses and other breeds reported in the literature. The RI of RBC in Lusitano horse $\left(6.2-9.6 \times 10^{6} \mathrm{~L}^{-1}\right)$ is similar to that of Spanish horses $\left(6.3-12.3 \times 10^{6} \mathrm{~L}^{-1}\right)$ (Muñoz et al., 2012) but lower than that of Standardbred horses in Italy (mean $9.11 \pm 0.67 \times 10^{6} \mathrm{~L}^{-1}$ ) (Padalino et al., 2014). The RI of HCT in the present study (29.5-45.3\%) is slightly higher than that of the Kiso horse (28.9-36.9\%) (Takasu et al., 2013) and working horses in Pakistan (2540.3\%) (Pritchard et al., 2009) but somewhat overlaps with that of Spanish horses (33-45.5\%) (Muñoz et al., 2012) and Thoroughbreds (37.9-45.5\%) or Standardbreds (34.8-41.8\%) (Moms, 1989). The mean MCV in Lusitano horses (47.4 \pm $2.2 \mathrm{fl}$ ) is higher than that of Standardbred horses in Italy (mean $42 \pm 2.62 \mathrm{fl}$ ) (Padalino et al., 2014), but lower than that of Spanish horses (mean $48.55 \pm 4.15 \mathrm{fl}$ ) (Muñoz et al., 2012). The mean MCHC in Lusitano horses (37.2 $\pm 1.5 \mathrm{~g} / \mathrm{dL})$ presents similarities to that of Standardbred horses in Italy (mean $36.94 \pm 0.6 \mathrm{~g} / \mathrm{dL}$ ) (Padalino et al., 2014) but is higher than that of Thoroughbreds $(31.5 \pm 2 \mathrm{~g} / \mathrm{dL})$, Arabians $(34.9 \pm 1 \mathrm{~g} / \mathrm{dL})$ and Lipizzaners $(31.4 \pm 0.94 \mathrm{~g} / \mathrm{dL})$ reported in equine medicine textbooks (Kingston, 2004a).

Regarding total WBC, the RI in Lusitano horses $\left(4.1-9.4 \times 10^{9} \mathrm{~L}^{-1}\right)$ overlaps the values reported from New Bolton Center $\left(4.9-10.3 \times 10^{9} \mathrm{~L}^{-1}\right.$ ) (Southwood, 2013) but is lower than the values for hot-blooded breeds (5.4-14.3 $\times$ $10^{9} \mathrm{~L}^{-1}$ ) published in an equine hospital manual (Kramer, 2000). The means of total WBC in Spanish horses $\left(11.35 \pm 3.4 \times 10^{9} \mathrm{~L}^{-1}\right)$ (Muñoz et al., 2012) and Arabian horses $\left(9.53 \pm 2.35 \times 10^{9} \mathrm{~L}^{-1}\right)$ (Kingston, 2004b) are higher than that found for the Lusitano horse $\left(6.8 \pm 1.3 \times 10^{9} \mathrm{~L}^{-1}\right)$. The RI for LYM found in the present study $\left(1-4.7 \times 10^{3}\right)$ is lower than that published for hot-blooded breeds in an equine medicine textbook $\left(1.5-7.7 \times 10^{3}\right)($ Kramer, 2000), and the mean of $\operatorname{LYM}(2.3 \pm 0.9)$ is also lower compared to that of Arabian horses $\left(4 \pm 1.3 \times 10^{3}\right)$ or Spanish horses $\left(5.34 \pm 3.12 \times 10^{3}\right)$ (Muñoz et al., 2012).

The use of inappropriate RI may lead to misinterpretation of laboratory results, resulting in inappropriate diagnosis and inadequate treatment (Friedrichs et al., 2012). In order to be transferable between breeds, reference intervals should come from a similar animal population and be collected under similar preanalytical conditions as those used by the adopting laboratory (Horowiz et al., 2008; 
Friedrichs et al., 2012). These facts emphasise the importance of performing standardized studies, according to ASVCP guidelines, with regard to autochthonous breeds in their own environment, which is the case of present study.

As stated before, several factors including sex and age may influence the haematological profile. As regards gender and age, the horses included in this study were at least 3 years old and males were overrepresented, although this was considered to be representative of the overall population of Lusitano horses in Portugal. Nevertheless, variations related to age were detected and a significant effect of sex on some parameters was found. In our study, differences related to age in $\mathrm{RBC}, \mathrm{MCV}$ and $\mathrm{MCH}$ are consistent with the results presented for other equine breeds, such as Thoroughbred and Spanish Purebred horses (Hernández et al., 2008) and Carthusian pregnant mares (Satué et al., 2009). In all these breeds, as in our study, a reduction in RBC count, with a compensatory increase in MCV and MCH, was associated with aging. The NEU/LYM ratio increased with aging, as previously described in other horse breeds (Jain, 1993; Hernández et al., 2008).

In horses, minor differences have been reported on the effect of sex on the haematological and biochemical parameters; however, there is a lack of consensus on this issue, mainly because the results were obtained in different breeds, which makes it difficult to compare them. In our study, females presented higher RBC, HTC and HGB than previously described for racing Arabian horses (Gill and Rastawicka, 1986). Regarding the WBC count, our results are similar to those reported by Satué et al. (2012); in particular, WBC counts are higher in females $\left(7.72 \pm 1.73 \times 10^{9} \mathrm{~L}^{-1}\right)$ than in stallions $\left(6.63 \pm 1.18 \times 10^{9} \mathrm{~L}^{-1}\right)$, as recently found in Spanish Purebred horses (Satué et al., 2012). However, a limitation of the present study is that the sample size did not allow the calculation of an RI for sex.

To the best of the authors' knowledge, this is the first report on the normal haematological reference intervals for adult Lusitano horses. The present results indicate that LaserCyte RI are acceptable for the clinical practice for all haematological parameters except MCHC, WBC, LYM and BASO, because for these latter parameters, after excluding the outliers as indicated by ASVCP guidelines (Friedrichs et al., 2012), more than $10 \%$ of the samples were out of the LaserCyte (IDEXX) RI values. For the latter parameters the following RI should be used: MCHC 33.7-39.6 g/dL; WBC 4.1-9.4 × 109/L; LYM 1-4.7 × 10\% $/ \mathrm{L}$; BASO $0-0.1 \times 10^{9} / \mathrm{L}$.

In conclusion, the haematological reference values established in this study represent valuable and applicable ranges for the haematological assessment of healthy adult Lusitano horses, providing useful information that could help clinicians to better interpret clinical data. However, further studies are needed in order to completely characterise the haematological RI of Lusitano horses, particularly on larger sample sizes that allow a more specific approach by age range, reproductive and athletic status. 


\section{Acknowledgements}

The authors are grateful to all horse owners for their kind collaboration during this study. This work was supported by the European Investment Funds through the FEDER/COMPETE/POCI - Operational Competitiveness and Internationalization Programme, under Project POCI-01-0145-FEDER-006958 and by the National Fund FCT Portuguese Foundation for Science and Technology, under project UID/AGR/ 04033/2013.

\section{References}

APSL (2012): The Lusitano Breed - History. Associação Portuguesa de Criadores do Cavalo Puro Sangue Lusitano, Cascais, Portugal.

Bazzano, M., Giannetto, C., Fazio, F., Rizzo, M., Giudice, E. and Piccione, G. (2014): Physiological adjustments of haematological profile during the last trimester of pregnancy and the early postpartum period in mares. Anim. Reprod. Sci. 149, 199-203.

Cunningham, E., Dooley, J., Splan, R. and Bradley, D. (2001): Microsatellite diversity, pedigree relatedness and the contributions of founder lineages to Thoroughbred horses. Anim. Genet. 32, 360-364.

Fazio, F., Assenza, A., Tosto, F., Casella, S., Piccione, G. and Caola, G. (2011): Training and haematological profile in Thoroughbreds and Standardbreds: a longitudinal study. Livest. Sci. 141, 221-226.

Friedrichs, K. R., Harr, K. E., Freeman, K. P., Szladovits, B., Walton, R. M., Barnhart, K. F. and Blanco-Chavez, J. (2012): ASVCP reference interval guidelines: determination of de novo reference intervals in veterinary species and other related topics. Vet. Clin. Pathol. 41, 441-453.

Geffré, A., Concordet, D., Braun, J. P. and Trumel, C. (2011): Reference Value Advisor: a new freeware set of macroinstructions to calculate RI with Microsoft Excel. Vet. Clin. Pathol. 40, 107-112.

Gill, J. and Rastawicka, M. (1986): Diurnal changes in the hematological indices in the blood of racing Arabian horses. Pol. Arch. Weter. 26, 169-179.

Hernández, A. M., Satué, K., Lorente, C., Garcés, C. and O’Connor, J. E. (2008): The influence of age and gender on haematological parameters in Spanish Horses. Proceedings of the 'Veterinary European Equine Meeting - XIV SIVE Congress', 25-27 January 2008, Venice, Italy. pp. $400-401$.

Horowiz, G. L., Altaie, S., Boyd, J. C., Ceriotti, F., Garg, U., Horn, P., Pesce, A., Sine, H. E. and Zakowski, J. (2008): Defining, establishing, and verifying reference intervals in the clinical laboratory; approved guideline - CLSI document C28-A3, Third edition. Clinical and Laboratory Standards Institute, Wayne, PA, USA.

Jain, N. C. (1993): Comparative hematology of common domestic animals. In: Jain, N. C. (ed.) Essentials of Veterinary Hematology. Lea \& Febiger, Philadelphia, USA. pp. 19-53.

Kingston, J. (2004a): Reference ranges for red cell variables in athletic horses. In: Hinchcliff, K. W., Kaneps, A. J. and Geor, R. J. (eds) Equine Sports Medicine and Surgery. Saunders, Edinburgh. pp. 1295-1296.

Kingston, J. (2004b): Reference ranges for the leukogram of athletic horses. In: Hinchcliff, K. W., Kaneps, A. J. and Geor, R. J. (eds) Equine Sports Medicine and Surgery. Saunders, Edinburgh. pp. 1297-1298.

Kramer, J. W. (2000): Normal hematology of the horse. In: Feldman, B. F., Zinkl, J. G. and Jain, N. C. (eds) Schalm's Veterinary Hematology, 5th edition. Willey-Blackwell, USA. pp. $1069-1074$ 
Leidinger, E. F., Leidinger, J., Figl, J., Rumpler, B. and Schwendenwein, I. (2015): Application of the ASVCP guidelines for the establishment of haematologic and biochemical reference intervals in Icelandic horses in Austria. Acta Vet. Scand. 57, 30.

Luis, C., Juras, R., Oom, M. and Cothran, E. (2007): Genetic diversity and relationships of Portuguese and other horse breeds based on protein and microsatellite loci variation. Anim. Genet. 38, 20-27.

Moms, D. D. (1989): Review of anemia in horses. Clinical signs, laboratory findings and diagnosis. Vet. Clin. North Am. Equine Pract. 11, 27-34.

Muñoz, A., Riber, C., Trigo, P. and Castejón, F. (2012): Age- and gender-related variations in hematology, clinical biochemistry, and hormones in Spanish fillies and colts. Res. Vet. Sci. 93, 943-949.

Padalino, B., Rubino, G., Lacinio, R. and Petazzi, F. (2014): Observations on the hematology of Standardbred Horses in training and racing in southern Italy. J. Eq. Vet. Sci. 34, 398-402.

Piccione, G., Casella, S., Giannetto, C., Messina, V., Monteverde, V., Caola, G. and Guttadauro, S. (2010): Haematological and haematochemical response to training and competition in Standardbred horses. Comp. Clin. Pathol. 19, 95-101.

Piccione, G., Vazzana, I., Giannetto, C., Gianesella, M. and Ferrantelli, V. (2008): Modification of some haematological and haematochemical parameters in horse during long distance rides. Res. J. Vet. Sci. 1, 37-43.

Pritchard, J. C., Burn, C. C., Barr, A. R., Whay, H. R. (2009): Haematological and serum biochemical reference values for apparently healthy working horses in Pakistan. Res. Vet. Sci. 87, 389-395.

Sample, S. H., Fox, K. M., Wunn, D., Roth, E. and Friedrichs, K. R. (2015): Hematologic and biochemical reference intervals for adult Friesian horses from North America. Vet. Clin. Pathol. 44, 194-199.

Satué, K., Blanco, O. and Muñoz, A. (2009): Age-related differences in the hematological profile of Andalusian broodmares of Carthusian strain. Vet. Med. Czech 54, 175-182.

Satué, K., Hernández, A. and Muñoz, A. (2012): Physiological factors in the interpretation of equine hematological profile. In: Lawrie, C. (ed.) Hematology - Science and Practice. InTech. Available from: http://www.intechopen.com/books/hematology-science-and-practice/ haematologicalprofile-of-the-horse-phisiological-factors-influencing-equine-haematology. pp. 573-596.

Silva, O., Silvestre-Ferreira, A. C., Cotovio, M., Colaço, A. and Pastor, J. (2010): Linearity of equine blood cell analyses with the LaserCyte hematology analyzer (abstract). Vet. Clin. Pathol. 39, 532-533.

Silvestre-Ferreira, A. C., Silva, O., Cotovio, M., Colaço, A. and Pastor, J. (2010a): Comparison of equine white blood cell differential counts between the LaserCyte haematology analyzer and the manual method (abstract). Vet. Clin. Pathol. 39, 532.

Silvestre-Ferreira, A. C., Silva, O., Cotovio, M., Colaço, A. and Pastor, J. (2010b): LaserCytedetermined equine erythrocytic variables in comparison to the Cell-dyn hematology analyzer and manual methods (abstract). Vet. Clin. Pathol. 39, 532.

Southwood, L. L. (2013): Normal ranges for hematology and plasma chemistry and conversion table for units. In: Southwood, L. L. (ed). Practical Guide to Equine Colic. John Wiley \& Sons, West Sussex, USA. pp. 339-342.

Takasu, M., Nagatani, N., Tozaki, T., Kakoi, H., Maeda, M., Murase, T. and Mukoyama, H. (2013): Hematological and biochemical reference values for endangered Kiso horse. J. Equine Sci. 24, 75-78.

Valera, M., Molina, A., Gutierrez, J. P., Gomez, J. and Goyache, F. (2005): Pedigree analysis in the Andalusian horse: population structure, genetic variability and influence of the Carthusian strain. Livest. Prod. Sci. 95, 57-66.

Vazzana, I., Rizzo, M., Dara, S., Niutta, P. P., Giudice, E. and Piccione, P. (2014): Haematological changes following reining trials in Quarter Horses. Acta Sci. Vet. 42, 1171. 
Vicente, A. A., Carolino, N. and Gama, L. T. (2009): Demographic parameters in Lusitano horse. Arch. Zootec. 58 (Suppl. 1), 501-504.

Vicente, A. A., Carolino, N. and Gama, L. T. (2012): Genetic diversity in the Lusitano horse breed assessed by pedigree analysis. Livest. Sci. 148, 6-25.

Zechner, P., Sölkner, J., Bodo, I., Druml, T., Baumung, R., Achmann, R., Marti, E., Habe, F. and Brem, G. (2002): Analysis of diversity and population structure in the Lipizzan horse breed based on pedigree information. Livest. Prod. Sci. 77, 137-146. 